DOI: https://doi.org/10.24297/jssr.v14i0.8357

\title{
Religion As A Determinant of Voter Behavior: An Analysis of The Relation Between Religious Inclination And Voting Pattern In Cross River State, Nigeria
}

\author{
Agbor, Uno Jim (Ph.D.) \\ Department of Public Administration, University Of Calabar, Calabar-Nigeria \\ kenijim@yahoo.com
}

\begin{abstract}
Religion and politics are two very important aspects of human society anywhere in the world. While religion addresses and conditions man's spiritual balance, politics shapes the practice of religion and determine who gets what, when, and how (Lasswell, 1958) in any given political setting. The belief in the supernatural can make people resist any perceived attempt to distort one's religious belief. An attempt to sustain one's religion, on the other hand, can determine the way one acts in the electoral process. In other words, the notion that a favorable polity guarantees the liberty to exercise freely one's religious rituals can influence the attitude and the way people act in deciding who should govern them. Religion and politics have come to be inseparable in man's quest for political power. In some societies, religion has been exploited to promote ascendancy to state power. This study assesses the relationship between religion and voter behavior in Cross River State, Nigeria, and whether religious consideration influenced the voting direction of electorates in 2011, 2015 and 2019 general elections. The rise of Islamic fundamentalism and segregate Pentecostalism in Nigeria's religious behavior justifies this study. The research hypothesizes that religious inclination tends not to have a significant effect on the voting pattern in Cross River State. Data was collected through a questionnaire from Christian churches and mosques in five locations in the state. A respondents sample size of 1,000 was got from the five locations covering the three senatorial districts. Data generated were analyzed with frequency count, percentages, and bar charts. The results show that respondents voted along religious lines in 2011, 2015 and 2019 general elections. Factors such as adherence to religious principles, pressure from religious superiors, denominational considerations accentuated this behavior. The study recommends, among others, that voter education should be intensified by civil society organizations on the danger of voting along with religious considerations.
\end{abstract}

Keywords: Religion, Election, Voting behavior, Politics.

\section{Introduction}

Religion and politics are two very important aspects of human society anywhere in the world. While religion addresses and conditions man's spiritual balance, politics shapes the practice of religion and determine who gets what, when, and how (Lasswell, 1958) in any given political setting. The belief in the supernatural can make people resist any perceived attempt to distort one's religious belief. An attempt to sustain one's religion, on the other hand, can determine the way one acts in the electoral process. In other words, the notion that a favorable polity guarantees the liberty to exercise freely one's religious rituals can influence the attitude and the way people act in deciding who should govern them. This goes to corroborate Abogunin's (1984) opinion that in the human social psyche, religion and politics are inseparable elements. Abubakar (1984) speaks of the Islamic religion as a good guide to political conducts.

Nigeria is a multi-religious society with three major dominant religious faiths, namely Christianity, Islam, and African traditional religions. There is, however, a fourth group that belongs to none of the above who refers to themselves as free -thinkers. They, however, do not command dominance in Nigeria's religious landscape. Principally, Christianity and Islam have been very recurrent in Nigeria's political sphere. Many public office seekers have largely exploited religious fanaticism to realize their political ambition. In Nigeria, pre and postelection violence have been very recurrent with the mass destruction of live and property. This ugly situation 
has been blamed largely on the reliance on religious faith in determining the political outcome. The recognition of the strength of religion on politics has produced a culture of joint ticketing of Moslem / Christian or Christian Moslem for the presidential candidate of any political party.

The choice of a political party flag-bearer and a running mate in Nigeria's political headship are defined on the ground of religious affiliation. If a Christian is a flag-bearer as in the case of President Goodluck Jonathan, the running mate must be a Muslim. It has remained a consistent practice in Nigeria political life, including the choice of state governors and their deputies where there two religions operate simultaneously.

The very reason adduced for this relationship is to place a check on state leadership not to use the advantage of state power to obscure other religious rituals and rivals or turn the state to a single religious state. It is also argued that members of each religion in power attempt to influence public policy in favor of areas where their religion is dominant, while religious faithful attracts contract from their religious brothers in power. All these seeming advantages tend to explain the inextricable link between politics and religion in Nigeria. In assuming political power, it is argued that religion has largely been used as a pathway. Theophilus Danjuma, cited in Asaju (1990) averred that religious fanaticism and favoritism have also been politically employed to polarize the people and sustain unhealthy tension in Nigeria. The description of religion as an opium of the many holds sway in Nigeria.

Cross River State is minority state with no strong political personality ever considered by dominant political parties to run for the office of the president. With no direct interest to protect, it is assumed that voting in the state will wear a choice that that may be conditioned by other sociological factors other than religion. Could this be true of electorates in Cross River State? Does religion influence the way faithful religious vote in Cross River State? Does the thesis of the secularisation theory hold sway in Cross River State? Are the attitudes of political office holders conditioned by their religious affiliation? How appropriate is it to relate religion with electoral politics? This stud, therefore, investigates religion as a factor in the voting behavior of electorates in Cross River State.

\section{The objective of the study}

The broad purpose of the study was to determine the propelling factor in voting behavior with a special focus on religion and to ascertain whether this played out in the Nigeria general elections of 2011, 2015 and 2019 in Cross River State. Specifically, the study seeks to determine:

1. Whether fundamentalism affects voter behavior

2. Whether spiritual Superiors influence the voting behavior of the religious faithful

3. Whether denominational differences within a religion influence electorates voting pattern

4. Whether electorates are consistently inclined to voting along religious lines.

\section{Research questions}

1. Does the strict adherence to your basic religious principles influence the way you vote and determines your voting pattern?

2. Does your Pastor/Imam influence the way you vote and openly tells the congregation how to vote?

3. Did they tell the congregation to vote along the religious line in the 2015 general election and to vote those that would protect their religion in the 2019 general elections?

4. Do you consider members of your denomination when voting before other candidates within your religion? 
5. In 2011, 2015 and 2019 general elections, did you vote along religious lines?

6. Will you vote a candidate from your religion in his second term bid if he did not perform well to your expectation in the first term?

\section{Area and scope of the study}

The study is situated within the political landscape of Nigeria. Located in the West African sub-religion, the country has an estimated population of $195,000,000$ people (NPC, 2006). It has in the past witnessed epileptic democratic elections, the first being in 1959 that ushered the first set of independent Nigeria. The next democratic election took place in 1979 and was followed by the 1983 general election which was cut short by the military overthrow of the civilian regime. However, the military experimented with some elections that suggested a form of unorganized diarchy principally aimed at buying time and elongating their stay in power. In 1998, the military conducted another election that ushered in a democratically elected regime on May 29, 1999. From then on, the country has had successive elections in 2003, 2007 and 2011, 2015 and 2019.

The scope of this study is limited to ascertaining whether religion influences the voting behavior of electorates in Cross River State and whether that played out in 2011, 2015, and 2019 general elections. The two religions studied in this work were Christianity and Islam. This is because they constitute the dominant religion in our clime and are at the core of consideration when voting is discussed along religious lines in Nigeria.

The study covers Calabar, Iwuru (Biase), Ugep, Ikom, and Ogoja. The choice of these locations in Cross River State is because of the appreciable presence of Moslem faithful and Christians who participated in all the elections. The distribution of respondents by location is presented in table 1 below:

Table 1: Distribution of Respondents by location

\begin{tabular}{|lllllll|}
\hline \multicolumn{1}{|c}{ Religion } & LOCATION & & & & & \\
& Calabar & Iwuru & Ugep & Ikom & Ogoja & Total \\
\hline Christianity & 200 & 75 & 75 & 75 & 75 & 500 \\
Islam & 200 & 75 & 75 & 75 & 75 & 500 \\
Total & 400 & 150 & 150 & 150 & 150 & 1000 \\
\hline
\end{tabular}

Source: Fieldwork, 2019

Four hundred respondents were selected from Calabar, while 150 respondents were taken from each of the other locations. Calabar was given a higher number because it harbors greater number of Christians and Moslems than the other locations.

\section{Methodology}

The study collected both primary and secondary data for analysis. The primary data were collected through the instrument of the questionnaire with the help of research assistants to guide those who cannot read and write in the English language. Primarily, the questions sought to elicit respondents' opinion on whether religion has any conditioning effect on their voting pattern. It also sought respondents' answers on whether religion informed their voting pattern in the 2011, 2015 and 2019 presidential elections in Nigeria. Secondary data were drawn from extant materials on religion and election in Nigeria. 
Respondents were mainly members of Christian churches and mosques. Deacons, Elders, Choristers also made the respondents list. We made sure that respondents were duly registered voters and voted during 2011, 2015 and 2019 general elections. Accidental and purposive sampling methods were used to select respondents. The choice of these sampling techniques was informed by the fact that the infinite and ambiguous nature of the population of the study area does not give room for random sampling. Data collected was analyzed qualitatively with a combination of frequency counts, percentages, and bar charts.

\section{Theoretical perspectives on religion and politics}

As defined by Emile Durkheim, cited in Aderibigbe and Aiyegboyin (1997), religion is a unified system of beliefs and practices which unite into one moral community called the church of all those who adhere to them. It is, therefore, the belief in and worship of a superhuman controlling power which could be the supreme God or gods. Shouler (2010) cited in Wikipedia summarizes the concept of religion as an organized collection of belief systems, cultural system, and world views that relate humanity to spirituality and sometimes to moral values.

Politics, on the other hand, is seen in its broadest se nse as power and therefore permeates all facets of the society. It, therefore, connotes the struggle for power to distribute scarce resources of the state. The whole exercise of politics is shrouded in power configuration, which is essential in determining action in the political system. People, therefore, seek power in the political system for both public (which include special groups) and personal aggrandizement.

As Duverger (1980: 109, 133-4) has observed,

"Holding a position of power gives one a considerable advantage; that the individuals, groups, and classes who exercise political power always assure for themselves great economic privileges and obtaining those privileges is the main reason for political struggle. People do not seek power for its own sake, but its benefits. Moreover, these benefits strengthen the position of those holding power."

This assertion explains the fierce contest in electoral politics in Nigeria as well as other developing democracies to gain control of the apparatuses of government for effective control of its resources. Politics, therefore, is concerned in this regard with how authority is used to allocate societal resources. This aligns with Easton (1979) conception of politics as the authoritative allocation of values. For him, politics involves the process through which the government responds to demands from its environment by allocating rewards, benefits, and penalties. This aptly corroborates Lasswell (1958) view of politics as involving the struggle among men to gain power or control at whatever level to determine who gets what resources, when and how. In its most obvious form, politics is a process of deciding, in the face of rather unyielding, conflicting or competitive opinions, what a group shall do, how it shall go about doing it and who shall have the power to decide things.

In modern democracies, elections possess the capacity to institute those who have the authority to decide the allocation of scarce state resources. In doing so, several factors are exploited to realize ascendancy to state power. One critical factor often employed is the reliance on religious faith. It is argued clearly that there is an inextricable link between religion and the behavior of individuals in electoral politics in very many multi-religious societies. However, the dimension of exploitation differs from society to society. Oguntola - Leguda's (2008) study of the Nigerian experience of the relationship between religion and politics concluded that religion and politics interact effectively in Nigeria. The work submitted clearly that religion had been used as a tool of political joggling and manipulation of the oppressed. In other words, most political violence which involves the masses so much is religiously induced. In spite of the negative uses of religion and politics, the author opined that there is the possibility of these two phenomena interacting positively to the benefit of the state and her citizens. The author, however, failed to point out how such benefit will come in a pluralized society with multi-religious faiths. A homogeneous society with a single dominant religion may witness a robust interaction between politics and religion for a positive effect. 
A multi-religious society with heterogeneous ethnic configuration would rather have religion interacting negatively for political gains. Davidson (2011) writing for open mind foundation argues along the line of the utility of the relationship between politics and religion in Nigeria. For him, nothing positive has come from the mix of politics and religion, either by way of economic growth, improved standard of living, reduction in unemployment, reduced consumption, improved infrastructure or improved security of lives and assets. Rather than using religion to improve governance at least in terms of moral sanctity, it has become an albatross on politics. Quoting Eso (2003) the author posited that mixing politics and religion has posed a grave danger in Nigeria. Our political leaders, on both sides, Muslims and Christians, have invoked the name of God in politics, and sought to use religion freely in influencing the polity, decision and swaying national political and economic policies and to that end governance. Mohammadu Buhari, a onetime presidential candidate for the All Nigerian Peoples Party (ANPP) a devout Muslim, had in the 2003 presidential election attempted to employ religion to further his presidential ambition by urging Muslims to vote only for their fellow Muslims. It is, therefore, healthy to align with Kew (2012) in this regard that politicians have been very apt to use religion and ethnicity for political mobilization purposes in Nigeria, and that has exacerbated the crises over the years.

The relationship between politics and religion in Nigeria remain extraordinarily complex. This is so because the two dominant religions are practiced in two major ethnic localities (North \& West) while the Igbo and the southsouth minorities practice Christianity. In other words, the two major religions are practiced in all parts of the country. This peculiarity places Nigeria in a safe secular status. The secularity of Nigeria, however, has consistently been threatened by the desire of religious independence. Regardless of its federal status, attempts have been made to turn some sections to Islamic states by declaring sharia. While this negates the provision of the constitution (section 10 precisely), it is not also feasible in a federal system of government. Nwabueze cited in Eso (2003) declared that state enforcement of sharia in all the plenitude of its injunctions, cannot in a multireligious society of Nigeria, co-exist with a truly federal form of political association. In addressing this troubling question of religion and Nigerian politics, Garba (2002) observed that the inability to maintain the principles of a secular nation and separate the state from religion had added another dimension to existing national tension. Consequently, with the introduction of sharia law by several state governments, national politics has all of a sudden become suffused with the deep-seated fear of Islam as a political force.

It is obvious from the above that religion is a strong factor not only in the spiritual practice of citizen but a determining factor in the Nigeria political sphere. President Jonathan agrees, clearly with this when he declared that some of the religious tensions in the country are politically motivated (Nnochia, 2012). The politicization of religion in clear terms also aggregates tension, which dove tail into conflict. The study of Ibrahim (1989) is very succinct on this assertion. Writing on the politics of religion in Nigeria, the author argues that the crises in Kaduna in particular emanated from the politicization of religion in the regimes' contest for power.

Cross country studies also affirm the close relationship between politics and religion. Writing on religion and perceptions of candidates' ideologies in the united state House elections, Jacobmeier's (2013) findings shows that religion has important independent effect on the evaluation of candidates' ideologies. The result of the study suggested that candidates affiliated with evangelical Christianity will tend to be seen as more conservative than ideologically similar mainline Protestants. Peralta (2012) study of the role of the Catholic Church in Mexico's political development shows that the Catholic Church in Mexico has not been an ideological state apparatus, as the church merely plays a role as auditor of public life.

Some theoretical foundations explain voting behavior. For instance, the thesis of the sociological approach centers on the impact social structures have on their members, and how they influence the choices they make in electoral politics (Alford, 1967; Lijphart, 1980). The election is a matter of choice, and electorates are tilted to voting candidates who will protect the interest of the social group. Religion is a social movement that is very sensitive to its environment, especially when contests over existence and relevance are involved. Religion also recognizes the power of secular authorities to determine its operations. Electorates with fundamentalist reasoning would consider a choice that would guarantee religious freedom and liberty. The works of Lipset and Rokkan (1967) dwells on cleavage structures in determining the emergence of political parties in a given polity. 
Political parties, in this case, emerge to protect the interest of some social groups. In the Nigerian context, some of the political parties that emerged in the first republic were driven by social group interest. NPC beyond having an ethnic coloration was also aptly concerned with protecting religious interest more so when its entire leadership structure was occupied by religious leaders. The United Middle Belt Congress also emerged to partly address the interests of the alienated Christians in the Northern region. Group identity affects attitude and interest and in turn, affects the way they vote (Egobueze and Ojirika, 2019). Political alignments become, therefore, a reflection of social cleavages. The voting model extrapolates religious, socio-economic, and other factors as major variables conditioning voting behavior. Choices that will best protect social group interest are supported in making electoral choices.

The secularization theory opines the irrelevance of religion in determining group interest in an organized society. The thesis holds that as societies advance in a modern and rational manner, religion loses its firm dominance in all aspects of social life (Norris \&Inglehart, 2004).

The theory argues that religion will fizzle out as society becomes more modern and will be so empty that it determines nothing. It argues that scientific development and intellectual advancement undermines consideration for the spiritual, supernatural, superstitious, and paranormal idea - the very foundation upon which religion rests for its legitimacy (Crabtree, 2016). Religion will become shallower as life becomes more differentiated into a modern aspect of work, politics, education, entertainment, etc. It will certainly begin to lose active membership and eventually become obscure. Great political and social thinkers such as Karl Marx, Emile Durkheim, Max Weber, Sigmund Freud (Bruce, 1992), had envisaged this decline. They argue that advancement in human development will make religion irrelevant and insignificant in the scheme of human consideration. Bainbridge puts it that social and intellectual progress is rendering religion obsolete. Mills (1959) had succinctly stated that religion would "disappear altogether except, possibly, in the private realm."

Wilson (1982) describes this condition as "the process by which religious institutions, actions, and consciousness, lose they're social significant." The question is, can religion stop determining behavior in a social group irrespective of the level of advancement? Has the thesis of the secularization theory explained the relationship between electoral politics and voting behavior in modern Nigeria? It is obvious even in highly advanced societies that the remnant of religion in motivating voting has not died. The same obtains in Nigeria.

The review above shows the inextricable link between religion and politics in human society. Scholarship on religion and politics in Nigeria have largely centered on what religion can do to politics from a perceptive point of view. In other words, the studies are largely opinions of scholars, and none has addressed this relationship in the context of Cross River State. This study, therefore, attempts an empirical survey of the impact of religion on the voting pattern in Nigeria's electoral politics with a specific focus on Cross River State. To this extent, the study exhibits originality and attempts to cover the existing gap in the literature.

\section{Results and discussion}

Data were descriptively presented using frequency counts, percentages, and illustrated in bar charts.

\section{Demographic information of respondents}

This section describes the demographic statistics of respondents in terms of religion, sex, age, and mental status. The result is presented in table 2 below. 
Table 2: Demographic information of respondents

\begin{tabular}{|lll|}
\hline & Frequency & Percentage \\
\hline Religion & 500 & 50 \\
Christianity & 500 & 50 \\
Islam & & \\
Sex & 600 & 60 \\
Male & 400 & 40 \\
Female & & \\
Marital Status & 550 & 55 \\
Married & 450 & 45 \\
Not married & & \\
\hline
\end{tabular}

Source: Fieldwork, 2019

One thousand respondents were involved in the study. Two known religions were considered for the study namely Christianity and Islam. The choice of these religions was made based on the consideration that they constitute the major contending religions in our locality and are often at the centre of discourses when religion is correlated with elections. 500 respondents represented each of the religions for the purpose of equality. 600 respondents were male representing 60 percent while 400 were females representing 40 percent. The disparity was not deliberately done. These were those who were willing to participate in the survey. About 550 respondents representing 55 percent were married while 450 representing 45 percent were not married. The age distribution of the respondents shows that about 600 representing 60 percent fell between the age brackets of 26-56 years old while 400 representing 40 percent were between the age brackets of 51-77 years old. The starting point of 26 years was to ensure that respondents were up to the voting age of 18 years by 2011 and should have participated in the voting process during the 2011, 2015 general elections and should have been familiar with the voting process by 2019.About 550 respondents representing 55 percent were married while 450 representing 45 percent were not married

\section{Fundamentalism and Voting pattern}

(a) Does the strict adherence to your basic religious principles influence the way you vote and determines your voting pattern?

The responses are presented in table 3 below:

Table 3: Responses on whether strict adherence to religious principles influence the voting pattern

\begin{tabular}{|lllllllllll|}
\hline & & \multicolumn{3}{l}{ Locations } & & & & & & \\
& Calabar & & Iwuru & & Ugep & & \multicolumn{2}{l|}{ Ikom } & & \multicolumn{2}{c|}{ Ogoja } & \\
& & & & & & & & & & \\
\hline Religion & Yes & No & Yes & No & Yes & No & Yes & No & Yes & No \\
\hline
\end{tabular}




\begin{tabular}{|lcccccccccc|} 
Christianity & 170 & 30 & 68 & 7 & 70 & 5 & 65 & 10 & 69 & 6 \\
Islam & 185 & 15 & 70 & 5 & 71 & 4 & 72 & 3 & 70 & 5 \\
Total & 355 & 45 & 18 & 12 & 141 & 9 & 137 & 13 & 139 & 11 \\
\hline
\end{tabular}

Source: Fieldwork, 2019

The result in table 3 above shows that the voting pattern of 355 respondents from Calabar are likely to be influenced by their religious principles during elections. 45 respondents are not influenced. In Iwuru-Biase 138 respondents vote along religious lines, while 12 respondents vote freely. 141 respondents from the Ugep location vote based on religion, while nine are not influenced by religion. 137 respondents from Ikom aver that the way they vote is determined by the religion they belong. 13 respondents do not vote along religious lines. In Ogoja, 139 respondents submitted that their religions principles and adherence to it influence their voting pattern while 11 respondents claim they do not vote along with religious persuasion.

The summary of responses on whether or not respondents vote along religious coloration is presented on table 4 below:

Table 4: Summary of responses on whether religion influences the voting pattern

\begin{tabular}{|lllll|}
\hline Responses & Christianity & Islam & Total & Percentage \\
\hline Yes & 442 & 468 & 910 & 91 \\
No & 58 & 32 & 90 & 9 \\
Total & 500 & 500 & 1000 & 100 \\
\hline
\end{tabular}

Source: Fieldwork 2019

The result from table 4 shows that 910 respondents representing 91 percent vote along religious lines, while 90 respondents representing 9 percent do not vote based on religions. The result also shows that the Moslems sampled are more inclined to vote along religious lines. This analysis is presented in the bar chart below:

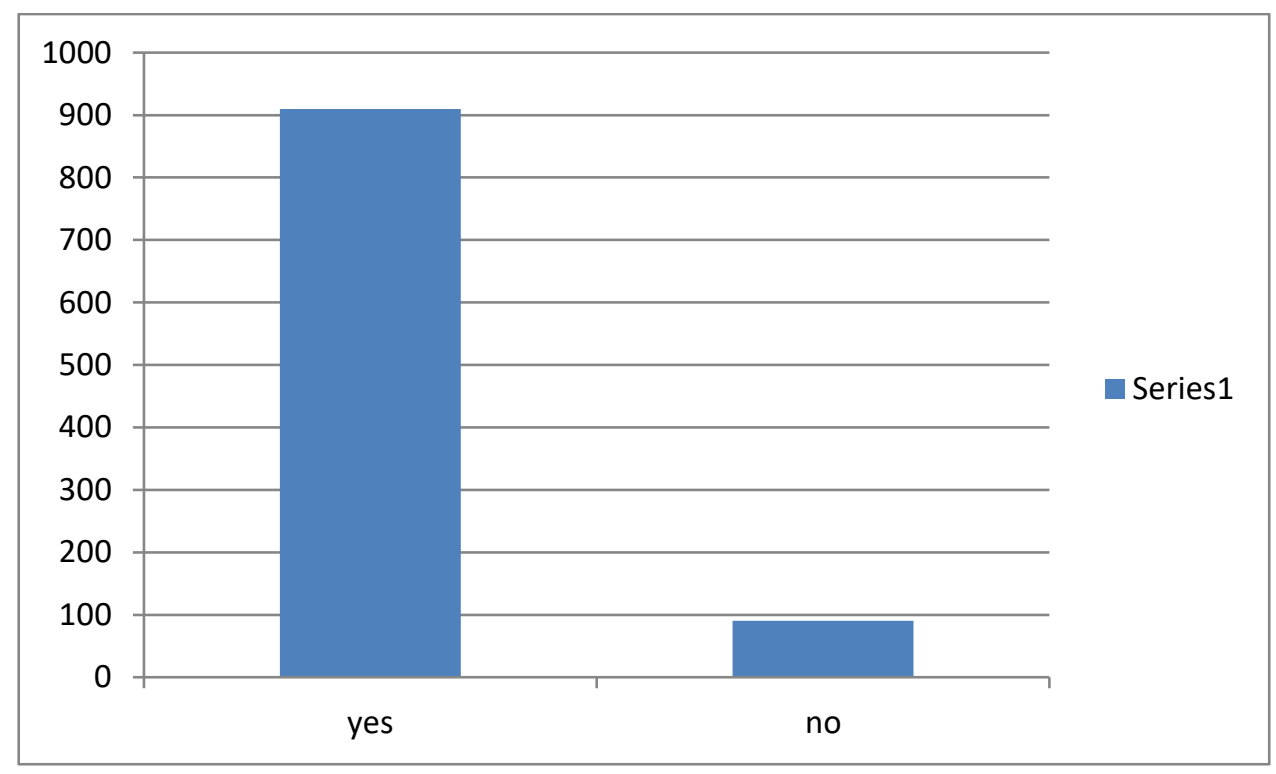

FIG.1: Bar chart showing whether religion influences their voting pattern. 


\section{RELIGIOUS SUPERIORS AND VOTING BEHAVIOUR OF CONGREGANTS}

By religious superiors, we mean heads of churches and spiritual leaders of worship centers. They include among others pastors and other clergies and Imams. On whether religious superiors influence members to vote along a given direction, the following questions were posed to the respondents:

(a) Does your pastor/imam influence the way you vote and openly tells the congregation how to vote?

(b) Did they tell the congregation to vote along the religious line in the 2015 general election are to vote those that would protect their religion in the 2019 general elections?

The responses to these questions are presented on tables and 5 and 6 below:

TABLE 5: Influence of religious superiors on voting pattern of congregants

\begin{tabular}{|lccc|}
\hline Religion & Yes & No & Total \\
\hline Christianity & 360 & 140 & 500 \\
Islam & 472 & 28 & 500 \\
Total & 832 & 168 & 1000 \\
\hline
\end{tabular}

Source: Fieldwork, 2019

The result shows that 832 respondents representing 83.2 percent submitted that their religious superiors (Pastors/Imams) have a tremendous influence on the way they vote and openly tells the congregation how to vote. 168 respondents representing 16.8 percent submitted that their clergies do not exert such influence on the congregation.

Table 6: Open admonition to vote along religious lines and religious protection in the 2015 and 2019 general elections

\begin{tabular}{|lccc|}
\hline \multicolumn{1}{|c}{ Religion } & Yes & No & Total \\
\hline Christianity & 359 & 147 & 500 \\
Islam & 470 & 30 & 500 \\
Total & 829 & 171 & 1000 \\
\hline
\end{tabular}

Source: Fieldwork, 2019

From table 6 above 829 respondents representing 82.9 percent agree that their religious superiors openly admonished them to vote along religious lines in the 2015 general elections and to vote those who would protect their religion in the 2019 general elections. On the other hand, 171 respondents representing 17.1 percent did not come under such admonition.

\section{Denominations and voting Pattern}

Different denominations exist within a given religion. The study sought to know whether this difference has a controlling effect on the way members of different denominations within the same religion vote. The respondents were presented with the following questions: 
(a) Do you consider members of your denomination when voting before other candidates within your religion?

The responses are presented in table 7 below:

Table 7: Religious Denominations and voting pattern

\begin{tabular}{|lccc|}
\hline Religion & Yes & No & Total \\
\hline Christianity & 420 & 80 & 500 \\
Islam & 450 & 50 & 500 \\
Total & 870 & 130 & 1000 \\
\hline
\end{tabular}

Source: Fieldwork, 2019

The responses on table 7 show that 870 respondents representing 87 percent consider members of their denominations when voting before any other candidates from the same religion. 130 respondents representing 13 percent do not consider denomination as a factor in their voting behavior.

\section{The consistent inclination to voting along religious lines}

Some behavior patterns tend to be consistent based on a belief system. Whether voting can be consistent on the part of religion was sought. The respondents on this basis were asked the following questions.

(a) In the 2011, 2015 and 2019 general elections, did you vote along religious lines?

(b) Will you vote a candidate from your religion in his second term bid if he did not perform well to your expectation in the first term?

Tables 8 and 9 below express the responses to these questions.

Table 8: Voting along religious lines in the 2011, 2015, and 2019 general elections

\begin{tabular}{|lccc|}
\hline Religion & Yes & No & Total \\
\hline Christianity & 460 & 40 & 500 \\
Islam & 455 & 15 & 500 \\
Total & 945 & 55 & 1000 \\
\hline
\end{tabular}

Source: Fieldwork, 2019

The result from table 8 shows that 945 respondents representing 94.5 percent voted along religious lines in the 2011, 2015 and 2019 general elections. It shows that religious consideration informed their choice of candidates in these elections. 55 respondents representing 5.5 percent did not vote along religious lines. The result is further presented in a bar chart below: 


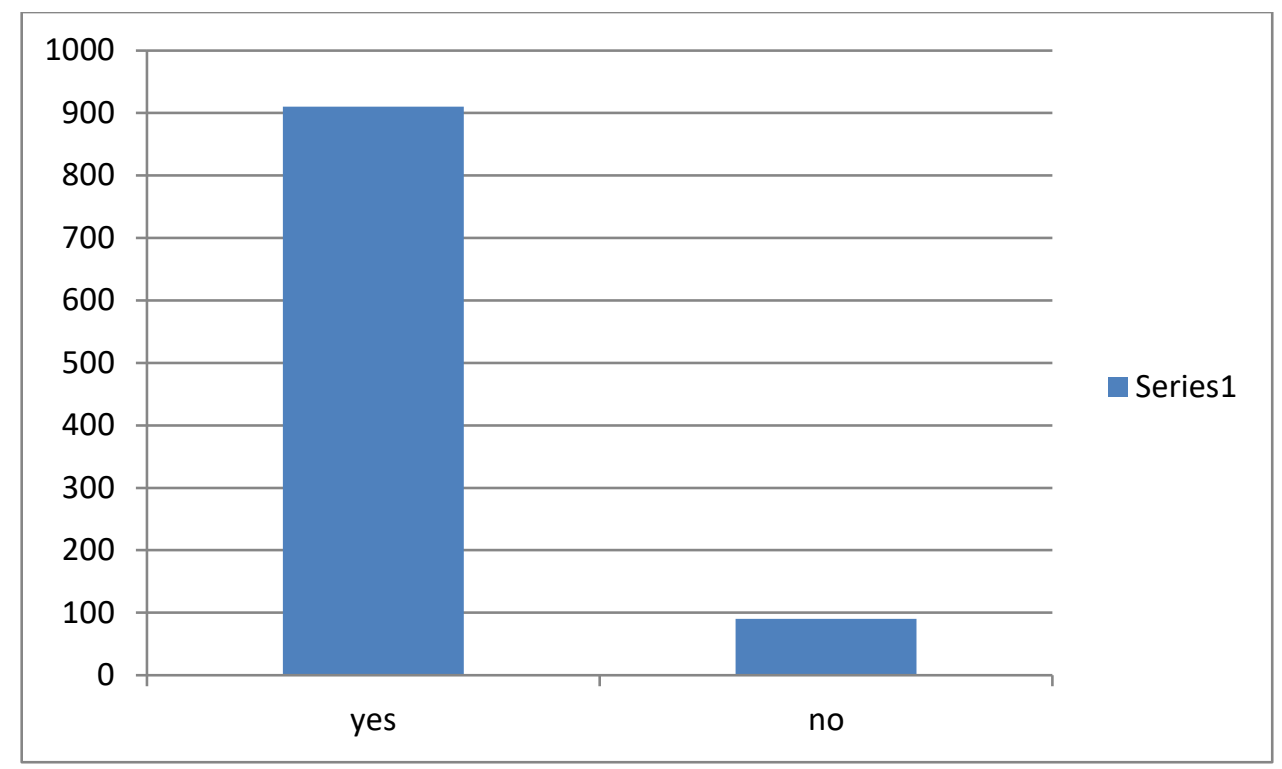

Fig 2: Bar chart showing responses on voting along religious lines in the 2011,2015 and2019 elections

Table 9: Consistent voting based on religion

\begin{tabular}{|lccc|}
\hline Religion & Yes & No & Total \\
\hline Christianity & 398 & 102 & 500 \\
Islam & 467 & 33 & 500 \\
Total & 865 & 135 & 1000 \\
\hline
\end{tabular}

Source: Fieldwork, 2019

The result above shows that 865 respondents representing 86.5 percent will consistently vote a candidate from their religion in the second term bid even if he did not perform satisfactorily in the first term. 135 respondents representing 13.5 percent would not vote a non performing member of their religions in the second term bid.

\section{Findings}

- The result in the area of fundamentalism shows that electorates adherence to their religious principles influences them to vote along religious lines.

- The second finding describes the association between religious superiors and voting pattern of congregants. It revealed that religious superiors (clergymen, Imams, and other religious leaders) influence the way their members vote and openly admonish them to vote along religious lines for the purposes of preserving and protecting their religion.

- Denominational considerations also influence the voting pattern of electorates. Within the same religion, segregation further exists in the choice of a candidate. Where two candidates from the same religion are contesting elections, respondents submitted that they would vote the candidate from his/her denomination irrespective of the personalities involved.

- Voting in the 2011, 2015 and 2019 was largely done along religious lines. The 2011 and 2015 presidential elections were largely expressed along religious lines. In the 2019 presidential elections, the two dominant parties (APC and PDP) presented candidates from one religion. Respondents submitted that they also voted 
along with religious consideration. This time they were considering the presidential candidate who will protect their religion and guarantee freedom of worship

\section{Discussion}

The study examined four core areas of religious pressure on voting behavior. These were:

1. Fundamentalism and voting pattern.

2. Religious superiors and voting pattern.

3. Religious denomination and voting pattern.

4. Consistent inclination to voting along religious lines.

The result in the area of fundamentalism shows that electorates adherence to their religious principles influences them to vote along religious lines. Religion is very dogmatic and teaches the acceptance of these principles as the only truth. It preaches the protection of its religion and realizes this protection partly from its members who are admonished to protect and defend the faith. Secular power is also considered a veritable avenue of protecting religious freedom and practice. The choice, therefore, of who administers state power becomes a dire concern for contesting religions in most societies, especially Nigeria.

Many studies have shown the close relationship between religion and electoral politics. Huntington (1993) had argued that religion is a strong factor driving international politics after the cold war. Fox (2001) and Philpott (2002) have come to the conclusion after studying the September 11, 2001 attack of the twin towers in the United States that religion still plays a serious role in politics and society. In the Nigerian context, religion has been very recurrent in its electoral politics. Onapajo (2016) argues that given the influential role religion plays in the social system of Northern Nigeria, religion is heavily touted for vote gain in the region. Early political parties founded in the region such as the Northern Peoples Congress (NPC), Northern Elements Progressive Union (NEPU), the United Middle Belt Congress (UMBC) all wore religious colorations. The influence of religion on the voting pattern was not restricted to the Northern region (Onapajo, 2016).

Religious consideration in voting has been a disturbing factor in Nigeria's electoral politics. Oboh (2017) submits that religion and ethnicity influenced the voting pattern in the 2015 general elections in Nigeria. Writing on religion and election in Nigeria from a historical perspective, Adamo (2018) observed that strong evidence exists of the serious aggressive influence of religion on Nigeria elections. He demonstrated the immense influence religion has had on the practice of Nigerian elections from the colonial period to 2015. Egobueze and Ojirika (2017) work on ethnicity, religion and voter's behavior: the experience of the 2015 presidential election in Nigeria, concludes that religion had a tremendous influence on the pattern of voting in 2015 presidential election.

The strength of religion in electoral politics is not only peculiar to Nigeria. Religion-motivated voting pattern has been very consistent in the American voting outcomes. Religious groups are very influential in American politics. Religious groups such as Catholics, Protestants, Evangelicals, and the Jews are very influential during presidential elections since the $19^{\text {th }}$ century (Browne, 2009). Manza and Wright $(2003$, p. 302) succinctly put it that the trend in history is that "the Republicans received very strong support from Episcopalians, Congregationalists, New School Presbyterians, and Methodists, while the Democrats draw support most heavily from Catholics and less broadly from Lutherans and Unitarians." Religion simply is a powerful tool in electoral politics.

The second finding describes the association between religious superiors and voting pattern of congregants. It revealed that religious superiors (clergymen, Imams, and other religious leaders) influence the way their 
members vote and openly admonish them to vote along religious lines for the purposes of preserving and protecting their religion.

The open pressure by religious leaders on their members to vote along their religion is a constant practice. In the second republic, it was played out. Eze (2009) averred that in the Nigerian Peoples Party (NPP) dominated Eastern Nigeria; the church openly campaigned for the party, and this tremendously accounted for its success and electoral victory in the region. In the 2003 general elections, it was alleged that Major General Buhari of the All Nigeria Peoples Party (ANPP) admonished Muslims not to vote for Christian candidates (Familusi, 2012). This brought about heavy criticism and may have accounted for a choice of a Christian pastor as a running mate in the 2011 elections to steal the hearts of Christian voters.

Goodluck Jonathan also wept the religious sentiments by attending frontline church programs and fraternizing with influential Pentecostal pastors who admonished their members to support him as a Christian candidate. Some pastors conspicuously campaigned for him. For instance, Paul Adefarasin of the House on the Rock Church urged his members to support a Christian presidential candidate in the 2011 elections (Onapajo, 2016).

In the United States, churches are so involved in politics and the political process. "They organize voting drives, distribute voter information guides, and state the church's stance on upcoming political issues and elections. Churches may encourage their congregants to prefer one candidate over another" (Straight-Reed, 2016).

Within the same religion, segregation further exists in the choice of a candidate. Where two candidates from the same religion are contesting elections, respondents submit that they would vote the candidate from his/her denomination irrespective of the personalities involved. In this case, religion is personal to an individual. An individual understands and believes in himself. Members of the same denomination believe and trust themselves to keep the faith and defend the religion. They may hardly see that commitment in another member of his religion that is not of his denomination. The battle between the orthodox Christians and Pentecostals explain this scenario. Again, the contest between radical Moslems and the moderate Moslems also addresses this position. It becomes very clear. Therefore, that denominational factor can also determine voting pattern within the same religion.

Voting in the 2011, 2015 and 2016 was largely done along religious lines. The 2011 and 2015 presidential elections were largely expressed along religious lines. In the 2019 presidential elections, the two dominant parties (APC and PDP) presented candidates from one religion. Respondents submitted that they also voted along with religious consideration. This time they were considering the presidential candidate who will protect their religion and guarantee freedom of worship. Most Christian respondents who voted the PDP presidential candidate Alhaji Atiku Abubakar though a Moslem, did so because they considered him a moderate Muslim who may not conceive the idea of Islamizing Nigeria and may guarantee religious freedom. Others saw Buhari as a radical Islamic fundamentalist who may not have toleration for other religions.

The rise of fundamentalism on both sides (Christians and Moslems) has brought about this mindset in voting in Nigeria. "Rather than seek a brotherhood of man, religious fundamentalism longs for a tribal community" (Okonkwo, 2018).

The rise of Boko Haram in the North-Eastern part of Nigeria, the penchant for the enthronement of sharia by some Islamic fundamentalists and the wanton killing of farmers in the Middle Belt by Herdsmen without convincing reprimand by the Nigerian State under the APC is enough to put chilling fears in the Christian community to think of voting a moderate Moslem in the state of dilemma they found themselves in the 2019 presidential elections.

Finally, respondents submitted that they would consistently vote candidate based on religion for a second term even if such candidates did not perform to expectation in the first term. Fear of extinction causes this kind of choice. Religion is considered the source of existence for adherents. Any secular power that is capable of 
threatening that existence is avoided consciously. If the avoidance has to come through the ballot, they will vote against such a candidate.

Voting along religious lines is a dogmatic inclination to choice making. It expresses blind voting and leads to wrong choices that manifest in underperforming public officers and the election of incompetent representatives.

Voting along with religious colorations also constantly grows timid electorates who see nothing wrong in underperforming public officials. Voting along religious considerations creates hatred among different religions and brings unnecessary tension and bigotry in the polity.

\section{Conclusion}

This study was conducted to determine the role religion plays in determining voting behavior in Cross River State, Nigeria, and whether it influenced the voting pattern of respondents in 2011, 2015, and 2019 General elections.

Variables of fundamentalism, the influence of religions superiors, religious denominations, and consistent voting patterns were examined as religious components that are likely to cause adherents to vote along religious lines. The sociological model of voting behavior and the secularization theory were used as theoretical guides to the study. The study found that adherence to strict religious principles, activities of spiritual superiors, denominational considerations influenced the voting pattern of respondents. Respondents also voted along religious lines in the 2011, 2015, and 2019general elections. In the case of the 2019 presidential election where the two dominant parties presented Muslim candidates, respondents said they still voted with religious considerations, this time along the line of which of the candidates will better guarantee religious liberty and freedom of worship. The two candidates were rated along radical fundamentalist Muslim and moderate Muslim. One striking contribution to knowledge here is that even within the reality of the dilemma of choice, voting can still be considered along religious lines. In this case, the choice of any of these unfavorable alternatives will depend on the electorates' perception who will guarantee freedom of religious practice and peace in religious relationship. The results refute the thesis of the secularization theory and conclude that religion plays a controlling force in determining the voting pattern of many electorates in Cross River State, Nigeria.

America, with its level of differentiation, still experiences voting behavior along religious lines. Until that level of differentiation is attained in Nigeria, religion will continue to determine behavior of social relationship and will continue to determine the voting pattern in Nigeria's electoral politics.

\section{Recommendation}

1. Voter education should be intensified by civil society organizations on the danger of voting along religious lines.

2. Ruling parties should strive to fulfill campaign promises and implement party manifestos to encourage electorates to vote based on what the party can offer to address public problems.

3. Political parties should encourage internal democracy by allowing popular candidates to become standardbearers.

4. Ruling parties and government should respect the secular identity of the state as enshrined in the constitution and should relate with citizens based on the law and not any other form of considerations

5. Campaigning along religious persuasion should be designated a crime against the state. It expresses hate disposition. 
6. Where it is substantially established that Religion was used to swing votes, the election of the candidate should be set aside.

\section{References}

1. Adamo, D. T. (2018). Religion and elections in Nigeria: a historical perspective. StudiaHistoriaeEcclesiasticae. 44 (3) pp. 1-19.

2. Aderibigbe, S. I., and Aiyegboyin, D. (1997). Religion: Study and Practice, ljebu-Ode: Alamsek

3. Abogunrin, S.O (1984). Towards a Unifying Political Ideology and Peaceful Coexistence in Nigeria: A Christian View. In Onaiyekan, J.O (ed.), Religion, Peace, and Unity in Nigeria, Ibadan: NACS.

4. Abubakre, R.D (1984). Islam Nostrum for Religious Tolerance in Polity of a Multi-Religious State: The Nigerian Experience. In Onaiyekan, J.O. (ed.), Religion, Peace, and Unity in Nigeria, Ibadan: NACS.

5. Asaju, D.F.,(1990) The Politicization of Religion in Nigeria. In Johnson, S.(Ed.), Readings in Selected Nigerian Problems, Lagos: Okanlawon Publishers.

6. Balogun, J.K (1995). Religion and Politics in Nigeria, What Future?. In Aderibigbe, I.S, and Ayegboyin, D.(Eds.). Religion and Politics, Lagos: NASRED

7. Bainbridge, W. S. (2011). Atheism. In P. B. Clarke (ed). The Oxford Handbook of the Sociology of religion. Oxford: Oxford University Press.

8. Browne, K. (2009). Religion and presidential elections: From accusations of Atheism

to proclamations of the Born-Again. Chrestomathy, 8, pp. 30-44.

9. Bruce, S. (ed) (1992). Religion and Modernization. Oxford: Oxford University Press: pp 170-179.

10. Crabtree, V. (2016). Definition of Secularization. Theory: Why is Religion declining? The Human Truth Foundation.www.humanreligions.info.

11. Davidson I. M. (2001). Nigerian Today, who is to blame - Religion, Nigerians, or both? www.openmindfoundation.com Retrieved 22/2/2013

12. Duverger, M. (1980). The Study of Politics. Nairobi: Thomas Nelson and sons.

13. Easton, D. (1959). The Political System. New York: Alfred A. Knopf.

14. Egobueze, D., and Ojirika, C. U. (2017). Ethnicity, religion, and voter's Behavior: The Experience of the 2015 presidential elections in Nigeria. Global Journal of Human Social Science-F. Political Science 17(4).

15. Eso, H.(2003). Nigeria: Religion as a tool of Politics. www.kwenu.com retrieved 21/2/2013

16. Eze, J. (2009). The church and presidential democracy: Political party elections in Igboland, 1979-2003. International Journal of Research in Arts and Social Sciences, 1, pp.160-169.

17. Familusi, O. O. (2012). Religious factors in the electoral process and Qatar an Enduring Democracy in Nigeria. Humanity and Social Science Journal 7 (1): pp.23-32.

18. Fox, J (2001). Religion: An oft-overlooked element of international studies. 
19. International Studies Review, 3, pp. 53-73.

20. Huntington, SP (1993). The clash of civilizations? Foreign Affairs, 72 (3) Pp.22-49.

21. Ibrahim, J. (1989). The politics of religion in Nigeria. Review of African Political Economy, 16, 45/46 pp.6583

22. Idowu, B.(1996). Olodumare: God in Yoruba Belief, Lagos: Longman.

23. IjimAgbor, U. (2005). Glimpses into Political Analysis: A Theoretical Orientation, Calabar: Offseason.

24. Jacobmeier, M. L. (2013). Religion and Perceptions of Candidates' Ideologies in the United State House Elections. Journal of Politics and Religion. Cambridge journals online.

25. Lasswell, H. (1958). Politics: Who Gets What, When, and How. New York: Meridian Press.

26. Lipset, S. M \& Rokkan, S. (1967). Cleavage structures, party systems, and voter alignments: an introduction. In S.M Lipset \& S. Rokkan (eds.), Party systems and voter alignments: cross-national perspectives, New York: Free Press.

27. Manza, J \& Wright, N. (2003). Religion and political behavior. In M Dillon (ed.),

28. Handbook of the sociology of religion, Cambridge: Cambridge University Press.

29. Matthew Kukah (1998). Religion and Civil Society. In Dukor,(Ed.), Philosophy and Politics: Discourse on Values and Power in Africa, Lagos: Obaroh and Ogbiriaka Publishers.

30. Nnochri, I. (November 23, 2013). Religious Tensions in Nigeria Politically motivated - Jonathan. Vanguard.

31. Norris, P., and Ingleharts, R. (2004). Sacred and Secular Religion and Politics worldwide. Cambridge: Cambridge University Press.

32. Oboh, G. E. (2017). Influence of ethnicity and religion in Nigerian elections and the imperative of media interaction. Sociology International Journal. 1(3) pp.79-84.

33. Oguntola-Logula, D. (2008). Religion and Politics in a Pluralistic Society: The Nigerian Experience. Journal of Politics and Religion, 12, 2, pp123-133

34. Okonkwo, C. (Feb. 6, 2018) (Muslim + Christian) Fundamentalism - A sinking country. Sahara Reporters.

35. Onapajo, H. (2016). POLITICS AND THE PULPIT: The Rise and Decline of Religion in Nigeria's 2015 Presidential Elections. Journal of African Elections. v15i2a6.Pp.112-135

36. Peralta, H. G. (2012). The Role of the Catholic Church in Mexico's Political Development. Journal of Politics and Development, 6, 1.

37. Philpott, D (2002). The challenge of September 11 to secularism in international Relations. World Politics. 55, pp. 66-95.

38. Shouler, K. (2010). The everything world religion book: Explore the Belief, Tradition, and Cultures of Ancient and Modern Religions. www.wikipedia.com Retrieved 3/3/2013

39. Straight-Reed, C. (2016). The Role of Religion in American Elections: Civil Engagement of Christians. Political Science. Pp.133-141. www.scholarworks.iu.edu. 